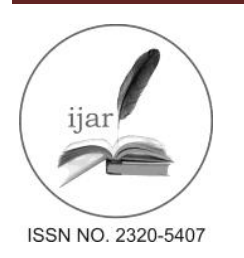
Journal homepage: http://www.journalijar.com

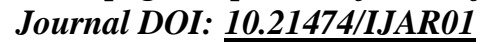

RESEARCH ARTICLE

\title{
IMPACT OF NUTRITION EDUCATION ON TRIBAL FEMALE APOLESCENTS OF BULDHANA DISTICT, MAHARASHTRA.
}

\author{
Dr. Mrs. Swati Chande and Smt. S R M Mahila Mahavidyalaya. \\ Associate Professor, M.Sc. (Food and Nutrition), M.A. (Home Economics), PhD. Department of Home Economics.
}

\section{Manuscript Info}

Manuscript History:

Received: 19 February 2016

Final Accepted: 29 March 2016

Published Online: April 2016

Key words:

Nutrition education, multi grain, germination, fermentation.

*Corresponding Author

Dr. Mrs. Swati Chande.

\begin{abstract}
Nutrition education is known to be important tool for improving the dietary pattern of the community. World Health Organization (WHO) has defined adolescent as the age between 10 to 19 years. Health scenario of the population would remain incomplete if adolescent group is excluded. About $80 \%$ of the tribal in India live in remote forest areas and hilly regions, without an access to the modern socio economic inputs. Current status of tribal population as reported 2011 census is $8.6 \%$ of the nation total population, whereas the tribal population of Maharashtra is 8.6 million. Tribal population of Buldana District is 115,000(Revenue division TRTI,Pune)Buldana District falls under Amravati division. Present study determines the effect of nutrition education on the tribal. A pre survey was conducted to impart nutrition education and post survey was conducted to see the effect of nutrition education. Five questions were framed like (Use of fresh vegetable and fruits, use of multi grain flour, method of germination, use of milk and milk product, method of fermentation). Pre and post responses were received. Purposive sampling method was use to collect data, interview and questionnaire was used to collect information. A positive effect of nutrition education was observed. To improve the nutritional health and status of tribal's, the nutritionist and dietitians should extensively carry nutritional educational programmes in the adjoining tribal area.
\end{abstract}

Copy Right, IJAR, 2016,. All rights reserved.

\section{Introduction:-}

The Tribal people are the most conservative orthodox and superstitious which impede their growth and development in all walks of life. India is considered to be an anthropological laboratory because of its religious social and linguistics, diversities. It has always attracted the attention of the world as being one of the oldest civilizations with kaleidoscopic variety of rich cultural heritage. About $80 \%$ of the tribal's in India live in remote forest areas and hilly regions, without an access to the modern socio - economic inputs. Most of the tribes are poor, backward and generally lead a hard and miserable life. Due to the part of developmental efforts, tribals are forced to rehabilitate in a totally new environment, settlement. But unfortunately because of the lack of education and the life of Comparative Exclusiveness, the scheduled tribes find these adjustments more difficult particularly in a alien location. Similarly sharp decline in the forest area and all forms of wild life brings in accelerated changes in their habits and practices and even in their lifestyles which are not conducive for their health and well being. The tribal's have their own socio-economic and cultural system and are mostly illiterate, ignorant and economically backward and have little awareness about hygienic living and nutritional food intake. Further limited means of subsistence addiction to alcohol, marriages at adolescent age, early pregnancies low birth weight babies are factors which adversely affect their health status.

It has been realized that by addressing the needs of the adolescent's one would not only be contributing to the socioeconomic development of the country but also to the special concerns like social harmony, gender justice, 
population stabilization and distinct needs which can no longer be overlooked. It is also very essential to invest in adolescents, as they are the future of the country. However, unfortunately studies on nutritional status of adolescents reveal need for improvement regarding health and diet for all strata of population like rural, urban, tribal, low income group, high income group etc.

Every society on the earth has its own distinct food habits and customs which mainly bases on local availability of food resources. Due to dearth of awareness and socio-economic conditions people especially the tribal folk suffer from under nutrition and malnutrition.

To satiate hunger or to fill stomach with food is not enough. A balanced diet i.e. scientific combination of nutritive ingredients like protein, facts, vitamins etc. with prescribed calorific value is necessary for proper and healthy growth of human body. Hence the need of nutrition education.

\section{Review of Literature:- Nutritional status:-}

Jayalaxmi, S and John K. R (2008) studied the Nutritional Status of Irular tribes, the heights and weights of adults and children were low compared to the general population in block.

Bhasin and Jain (2007), Assessed nutritional status of adolescent tribal groups of Rajasthan. Heights and weights were collected and the mean values compared with standards. Results revealed a high prevalence of stunting (low height for age) and under weight (low weight for age) among both males and females. Females showed a higher percentage prevalence of chronic malnutrition $(<90)$, with respect to height and also under weight then the males. Most samples fall much below the normal (75') standards weight for age.

Singh et al (2007), assessed nutritional status of boys of the Spitian tribe of Himalayas with age ranging from 5-20 years, results revealed that diets is deficient in nutrients, thus the subjects from the age group are highly vulnerable affecting upon their health.

Rao, et al (2006), observed nutritional status of adolescent tribal population in nine states of India. Results reveal 63 $\%$ of adolescent boys and $42 \%$ of girls were undernourished (<5 BMI age percentile of NHAES). A significant association between under nutrition and socio economic parameters like type of family, size of land holding and occupation of head of house hold was observed.

Meshram and Damayanti (2004), observed growth and nutritional status of tribal adolescents in Madhya Pradesh. It was found that prevalence of under nutrition was high in boys than in girls; however as age advanced the prevalence of under nutrition was same in both the sexes.

Above references reflect about poor nutritional status among tribal's and need of nutritional education would help in improving their nutritional status.

\section{Nutrition Education:-}

Shunumukha, Priya, Kausalya, S (2013) Studied effect of nutrition education and raising kitchen garden on Iron and Vitamin nutriture of Adolescents. The blood hemoglobin levels increased from $10.77 \mathrm{~g} / \mathrm{dl}$ to $11.05 \mathrm{~g} / \mathrm{dl}$ to $10.98 \mathrm{~g} / \mathrm{dl}$ for control group. Vitamin A level increased from $26.84 \mathrm{mg} / \mathrm{dl}$ to $27.36 \mathrm{mg} / \mathrm{dl}$ among experimental group and 26.86 $\mathrm{mg} / \mathrm{dl}$ to $27 \mathrm{mg} / \mathrm{dl}$ among the control group after raising kitchen garden.

Deepa Prakash and Jamuna Prakash (2012) studied nutrition education on nutrition knowledge of children and their parents and food behavior of children. The results revealed nutrition education improves nutrition of children on their parents which in turn improve their food behavior and dietary diversity.

Gowri B. and Vasantha Devi K.P. (2011) studied impact of nutrition education in nutrition and food safety practices among self help group woman. The impact of food safety education improved their knowledge on safe food handling practices and personal hygiene.

Rohini C. and Yegammai Tiwari (2011) observed impact of nutrition education of positive therapy on stress and anxiety in school going adolescents. Results revealed after imparting nutrition education stress and anxiety was minimized and status of hemoglobin also improved. 


\section{Aim of study:-}

Looking at the above health and nutritional scenario of tribal adolescents in India and effect of nutrition education, the present study aimed imparting nutrition education and studies its effect.

\section{Methodology:-}

The details of methodology are presented in following paragraph .

1. Selection of area: The objective of present study was to cover adolescent girls. It was therefore planned to reach the same Tribal infested area the tehsils of Buldhana district namely of Sangrampur and Jalgaon-Jamod were selected for study. While selecting area it is important to know tribal population of region and district. Tribal population of Amravati division 1,116 thousand and that of Buldhana district being 115 thousand (Revenue division, TRTI, Pune.) Buldhana district comes under Amravati region.

2. Duration of survey: Duration of survey continued for one year. Several small visits as when required were observed. Hilly areas were not accessed during rainy season.

3. Subjects: Subjects included adolescent girls (including pregnant status)

\section{Description of tools and techniques used in survey.}

1) Sampling Technique: Purposive sampling method was used to collect data. Since only adolescent group was assessed purposive method of sampling was adopted.

2) Statistical Survey: Collection of data from tribal household on the basis of questionnaire and interview method. Responses tabulated and subjected to statistical analysis.

3) Interview: Illiteracy a major hurdle with respect to recording responses from questionnaire, hence tribals were interrogated and responses were filled in. Selected informants like anganwadi sewika, local inhabitants, school teachers, doctors were interrogated for relevant information.

4) Questionnaire: A well structured pretested questionnaire was framed to collect relevant information.

5) Pre \& post survey: Nutrition education is known to be important tool for improving the dietary pattern of community. An attempt was therefore made to educate the subjects under study on simple facts about day to day foods to be taken and their importance in diet. However a pre survey was conducted to assess their knowledge before nutrition education and a post survey was conducted after nutrition education and the responses tabulated.

6) Nutrition Education: Five simple questions were framed and pre and post responses received from the questions like:

i) Use of fresh vegetable and fruits.

ii) Use of Multi grain flour.

iii)

germination.

$$
\begin{aligned}
& \text { iv) Use } \\
& \text { product. }
\end{aligned}
$$$$
\text { v) }
$$

Fermentation.

\section{Result and} The pre and post received from the are represented results discussed paragraph.
Method of of Milk and Milk Method of

\section{Discussion:-} survey responses above questions graphically and in the following 
First bar represents use of fresh fruits and vegetables. Fresh fruits and vegetables provide vitamins and minerals. Tribals from the area purchase fresh fruits and vegetables from the weekly market. After nutrition education and by explaining that fresh fruits and vegetables will keep them healthy and free from diseases the response showed a significant rise, i.e. from $10 \%$ to $50 \%$.

Second bar represents use of multi grain flour. Tribal's use the multi grain flour in emergency when one of the flour was less like mixing of Jowar, Wheat flour and Maize flour. After explaining the benefit of multi grain flour the response rose from $20 \%$ to $70 \%$.

Third bar represent method of germination. Legumes and pulses were cultivated in the tribal area. However, only few knew about method of germination. With germination there is rise in vitamin $\mathrm{C}$ content and vitamins from the B - complex group. After explaining the benefits of the same $90 \%$ of tribal's followed the method of germination.

Fourth bar represents use of milk and milk products. There is a popular belief among tribal's that milk of animals is meant for the baby and it is improper to milch the animal. After explaining that after the baby drinks milk, remaining milk can be milched as milk is very essential for strong bones and teeth. The response rose from $20 \%$ to $80 \%$.

Fifth bar represents method of fermentation. Multi grain flour was mixed with butter milk and left for fermentation, making of Dhokla was demonstrated and its nutritional importance was explained, $70 \%$ of tribal's followed the procedure.

\section{Conclusion:-}

From the above results it can be concluded that nutrition education had positive effect in following the procedures. To improve the nutritional health status of tribal's the nutritionist and dietitians should extensively carry nutrition education programs in the adjoining tribal areas. They should also train some tribal adolescent who can guide the population during absence of nutritionist.

\section{References:-}


1. (Raoet.al.2006): Rao K.M.N, Balkrishna, A., Laxmaih, K., Venkaih. G. Brahmam. (2006), "Diet and nutritional status of adolescent tribal population in nine states of India". Asia Pacific Journal of Clinical Nutrition. Vol-15, P-64-67.

2. Bhasin and Jain (2007): Bhasin M.K. and Jain Sweta (2007), "Biology of the tribal groups of Rajasthan, India: Assessment of Nutritional status using heights and weights". Anthropologist, Vol-9, P-181-197.

3. Deepa Prakash and Jamuna Prakash (2012) "Impact of Nutrition Education Knowledge of Children and their Parents and Food Behavior of Children." Indian Journal of Nutrition and Dietetics, Volume 49, P - 341 .

4. Gouri B. and Vasantha Devi. K.P. (2011) "Impact of Education in Nutrition and Food Safety Practices among Self Help Group Woman. Indian Journal of Nutrition and Dietetics. Volume - 48, P - 407.

5. Meshram and Damayanti (2004), Meshram Pradeep and Damayanti, K. (2004), "Growth and Nutritional status tribal and non tribal adolescents in Madhya Pradesh". Scientific programmes abstracts of talks and abstracts of posters. Nutrition society of India, XXX V1, annual meet, November, 2004. Mysore. P-103.

6. Rohini C. and Yejammai Tiwari (2011) "Impact of Nutrition Education and Positive Therapy on Stress and Anxiety in School going Adolescents. Indian Journal of Nutrition and Dietetics. Volume - 48, P-469.

7. Shunumukha Priya, S and Kowsalya (2013) "Impact of Raising Kitchen Garden And Nutrition Education of Iron and Vitamin A Nutriture of Adolescents.” Indian Journal of Nutrition and Dietetics, Volume - 50, P - 181 .

8. Singh et al (2007): Singh, S.P., Malhotra P., Sidhu, L.S. and Singh Prit Pal. (2007), "Nutritional assessment of boys of the Spitian Tribe of the Himalayas" Journal of Human Ecology, Vol-21, P-279-284.

http://www.google .co. in (current tribal population census 2011). 